\title{
Potential of Turmeric (Curcuma Longa) in Increasing Hemoglobin Levels: Systematic Literature Review
}

\author{
Siti Nadirah $^{1 *}$, Donny Kristanto Mulyantoro², Sri Wahyuni ${ }^{3}$ \\ ${ }^{I}$ Poltekkes Kemenkes Semarang, Indonesia \\ ${ }^{2}$ Balai Litbang Kesehatan Magelang, Indonesia \\ ${ }^{3}$ Poltekkes Kemenkes Surakarta, Indonesia \\ *sitinadirah536@gmail.com
}

\begin{abstract}
According to WHO, it is estimated that $30 \%$ of the world's population has anemia, $27 \%$ of anemia occurs in developing countries and $6 \%$ occurs in developed countries. Anemia is a condition in which red blood cells do not meet the body's physiological needs. Untreated anemia can cause various risks to health. The handling of anemia by the government has not been maximized so that companion therapy is needed. Several studies have shown that turmeric has the potential to increase hemoglobin levels.

The aimed of this study was to determine the potential of turmeric (curcuma longa) to increase hemoglobin. The search method in this literature uses electronic data from Scopus, Pubmed, Elsevier, Willy and Google Scholar published from 2010-2020. The keywords used in the search were (1) "Curcuma Longa", (2) "hemoglobin", (3) "anemia". Articles that are irrelevant and do not meet the criteria are not used. The research was conducted on humans with this type of experimental research. Compiled with prism techniques for the review of title, abstract, full text and methodology assessed for study eligibility. From all search results, there were 25 articles related to research on subjects with various blood loss diseases. 2 articles studied hemodialysis patients, 7 articles examined thalassemia patients, 3 NAFLD patients, 4 ulcerative colitis patients, 1 prehypertensive patient, 3 diabetes patients, 1 metabolic syndrome patient, 1 patient with elevated alanine transaminase (ALT), 2 patients with arthritis and 1 in patients with breast cancer. Based on the analysis of 25 articles related to turmeric research (curcuma longa) in subjects with various diseases related to blood loss, there are only 3 articles that show an increase in $\mathrm{Hb}$ levels after giving Curcuma Longa both in terms of effect size and from the p-value, These 3 articles were conducted by Jirawan Panachan, Hamid Reza and Orn Uma. So it can be concluded that Curcuma Longa Is Not Effective In Increasing Hemoglobin Levels.
\end{abstract}

Keywords: Anemia, Curcuma longa, Hemoglobin 


\section{STRADA Jurnal Ilmiah Kesehatan}

DOI: $10.30994 /$ sjik.v9i2.482

ISSN: 2252-3847 (print); 2614-350X (online)

Vol.9 No.2 November 2020 Page.1422-1433

\section{BACKGROUND}

The health status of a country can be seen from the Maternal Mortality Rate (MMR). Based on data from the World Health Organization(WHO)in 2017, the MMR globally was 216 per 100,000 live births. ${ }^{1}$ The study states that from 2003 to 2009 in 115 countries, the most common causes of maternal death were bleeding, hypertension, and sepsis. ${ }^{2}$ Maternal Mortality Rate (MMR) in Indonesiais based on the results of the Inter-Census Survey (SUPAS) in2015, namely 305 per 100,000 live births $(\mathrm{KH}) .^{3}$

Anemia is a non-obstetric factor in AKI that is related to the health status of the mother. Different prevalence of anemia is found in various countries. ${ }^{4}$ According to $\mathrm{WHO}$, it is estimated that $30 \%$ of the world's population has anemia, $27 \%$ of anemia occurs in developing countries and $6 \%$ occurs in developed countries ${ }^{5}$ The results of Riskesdas in 2013, the incidence of anemia in Indonesia reached $21,7 \% .^{6}$ The incidence of anemia based on the stages of age 5-14 years is $24.4 \%$, aged $15-24$ years is $18.4 \%$, aged $25-35$ years is $16.9 \%$ and $33-44$ years reaches $18.3 \% .^{7}$

Some government efforts in dealing with anemia are given based on pharmacological and non-pharmacological therapies. One of the pharmacological therapies is the provision of blood-supplemented tablets. ${ }^{8}$ Blood-added tablets are given with one tablet containing $60 \mathrm{mg}$ of ferrous sulfate and $0.25 \mathrm{mg}$ of folic acid. For adolescents, the Fe tablet was given once per week, while 10 tablets were taken during menstruation. The recommendation for iron supplementation is an effort to prevent and overcome iron nutrition anemia. $^{9}$

However, the government's efforts in overcoming the problem of nutritional anemia have not always gone well and effectively. Research by Briawan shows that giving Fe tablets to junior high and vocational high school students do not increase hemoglobin levels. ${ }^{9}$ Therefore, many people switch to using non- pharmacological therapies for treating anemia, including tomatoes, amla leaves, and turmeric. ${ }^{10,11}$

Meanwhile, another study conducted by Nella nor with the intervention of turmeric (Curcuma Longa) showed that the Hb value in experimental animals had increased. ${ }^{12}$ Studies conducted by Khoirina on experimental animals with the intervention of giving turmeric water (CurcumaLonga) showed no signi cant difference in $\mathrm{Hb}$ levels between groups. ${ }^{13}$

\section{MATERIALS AND METHODS \\ Search strategy}

This literature review uses articles from various databases such as Google Scholar, Pubmed, Scopus, and Willy, Elsivier Published 2010-2020. the keywords used were anemia, curcuma longa, hemoglobin.

\section{Inclusion and exclusion}

The inclusion criteria used in this study were, using Indonesian and English, the journals used were 2010-2020, RCT research, contained turmeric and hemoglobin, full text of the article. As for the exclusion criteria, the results of the study were incomplete data, meta-analysis.

\section{Data Extraction}

The authors extract the research articles obtained to be adjusted based on inclusion and exclusion criteria, and detect duplication of research articles. The results of the extraction of research articles are presented in a table containing the title of the article, the author's name, year, samples, and the intervention. 


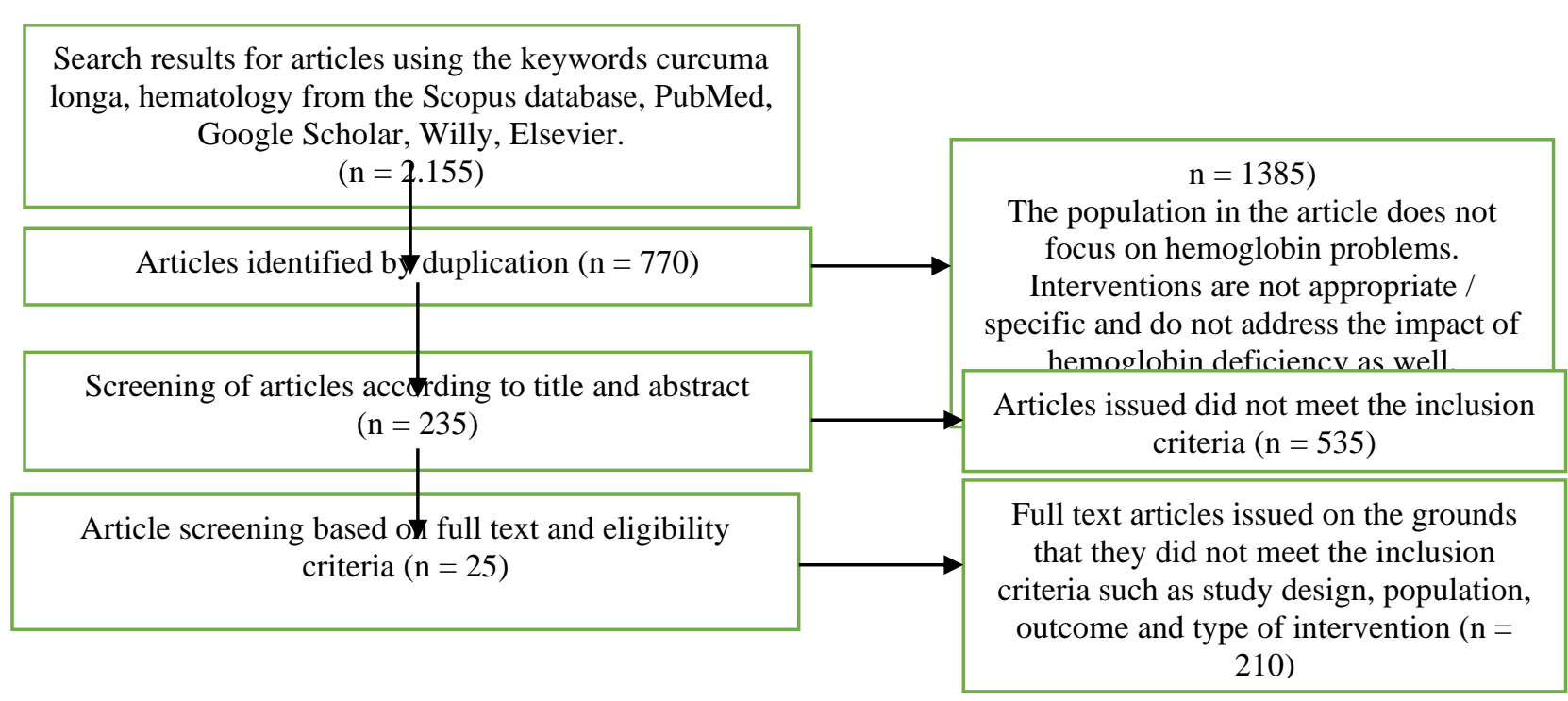

\section{RESULTS}

Search results for articles using the keywords curcuma longa, hematology from the Scopus database, PubMed, Google Scholar, Willy, Elsevier $(\mathrm{n}=2.155)$. Articles were identified by duplication $(n=770)$. The population in the article did not focus on hemoglobin problems $(n=1385)$. Interventions are not appropriate / specific and do not address the impact of hemoglobin deficiency as well. Screening of articles according to title and abstract $(n=235)$. Articles excluded did not meet the inclusion criteria $(n=535)$. Article screening based on full text and eligibility criteria $(n=25)$. Full text articles issued on the grounds that they did not meet the inclusion criteria such as study design, population, outcome and type of intervention $(n=210)$

\section{Table 1. Summary of Selected Studies}

\begin{tabular}{|c|c|c|c|}
\hline NO & Researcher & Research methods & Research result \\
\hline 1 & $\begin{array}{l}\text { Maryam } \\
\text { pakfetrat } \\
\text { Iran } \\
(2014)^{14}\end{array}$ & $\begin{array}{l}\text { The study design with RCT and study } \\
\text { population was carried out on } 48 \\
\text { hemodial patients aged } 18-60 \text { years. } \\
\text { administration of } 500 \mathrm{mg} \text { of turmeric } \\
\text { powder }\end{array}$ & $\begin{array}{l}\text { The } \mathrm{Hb} \text { value in the study intervention } 0,46 \\
\text { group was carried out for } 8 \text { weeks } \\
\text { before } 11.3 \pm 2.1 \text { after } 11.5 \pm 1.9 \\
\text { Hb on placebo administration } \\
\text { before } 10.9 \pm 1.6 \text { after } 12.3 \pm 1.5 \\
(\mathrm{p}=0.425)\end{array}$ \\
\hline 2 & $\begin{array}{l}\text { Ruchaneekorn } \\
\text { W. } \\
\text { Bangkok } \\
(2010)^{15}\end{array}$ & $\begin{array}{l}\text { Research design using RCT, the study } \\
\text { was conducted on } 21 \text { patients with } \\
\text { thalassemia, given turmeric } \\
\text { intervention } 250 \mathrm{mg} 2 \mathrm{x} / \text { day a total } \\
\text { of } 500 \mathrm{mg} \text { and } 29 \mathrm{samples} \text { were given } \\
\text { a placebo. }\end{array}$ & $\begin{array}{l}\mathrm{Hb} \text { value }(\mathrm{g} / \mathrm{L}) \text { in the intervention } 27.0 \\
\text { group. The study was conducted for } 12 \\
\text { week } \\
\text { before } 69 \pm 3 \text { after } 69 \pm 3 \\
\text { Hb values in healthy samples were } 138 \pm \\
2\end{array}$ \\
\hline 3 & $\begin{array}{l}\text { Yunes Panahi } \\
\text { Iran } \\
(2019)^{16}\end{array}$ & $\begin{array}{l}\text { Design: RCT, } \\
\mathrm{N}: 70 \text { (control: } 35 \text {, intervention } 35 \text { ) } \\
\text { with non alcoholic fatty liver disease } \\
\text { (NAFLD) patients. } \\
\text { Giving } 500 \mathrm{mg} \text { of turmeric }\end{array}$ & $\begin{array}{l}\mathrm{Hb} \text { value in the turmeric intervention } 1.86 \\
\text { group } \\
\text { before } 15.26 \pm 0.26 \text { after } 14.57 \pm 0.28 \\
\text { Hb values in the placebo group } \\
\text { before } 14.88 \pm 0.28 \text { after } 14.13 \pm 0.18\end{array}$ \\
\hline 4 & $\begin{array}{l}\text { Alon } \\
\text { Alang } \\
\text { Islael } \\
(2015)^{17}\end{array}$ & $\begin{array}{l}\text { Design: RCT, } \\
\mathrm{N} \text { : } 50 \text { patients with ulcerative colitis } \\
\text { (control: } 24 \text {, intervention } 26 \text { ) } \\
\text { Giving } 500 \mathrm{mg} \text { of turmeric }\end{array}$ & $\begin{array}{l}\text { Value of } \mathrm{Hb} \mathrm{g} \mathrm{/} \mathrm{dL} \mathrm{( \% )} \text { in intervention: - } \\
12 \% \\
\text { control: } 4 \% \\
\text { The results of the study for } 1 \text { month }\end{array}$ \\
\hline
\end{tabular}




\begin{tabular}{|c|c|c|c|}
\hline & & & $\begin{array}{l}\text { showed no significant increase in the } \\
\text { increase in } \mathrm{Hb} \text { with curcumin } \\
\text { administration. }\end{array}$ \\
\hline 5 & $\begin{array}{l}\text { Narges Sadeghi } \\
\text { Iran } \\
(2019)^{18}\end{array}$ & $\begin{array}{l}\text { Design: } \mathrm{RCT} \text {, } \\
\mathrm{N}: 70 \text { patients with ulcerative colitis } \\
\text { (control: } 35 \text {, intervention } 35 \text { ) } \\
\text { Giving } 1,500 \mathrm{mg} \text { of turmeric }\end{array}$ & $\begin{array}{l}\text { Hb value on turmeric for } 8 \text { weeks } \\
\text { before } 13.2 \pm 1.29 \text { after } 13.2 \pm 1.18 \\
\text { on a placebo } \\
\text { before } 13.3 \pm 2.03 \text { after } 13.2 \pm 1.9 \\
\mathrm{p}=0.941\end{array}$ \\
\hline 6 & $\begin{array}{l}\text { Ryusei Uchio } \\
\text { Jepang } \\
(2019)^{19}\end{array}$ & $\begin{array}{l}\text { Desain : RCT, } \\
\mathrm{N}: \quad 90 \text { pasien Pasien pre } \\
\text { prehipertensi (kontrol: } 45 \text {, intervensi } \\
\text { 45) } \\
\text { giving } 900 \mathrm{mg} \text { of turmeric }\end{array}$ & $\begin{array}{l}\text { Research conducted for } 12 \text { weeks - } \\
\text { showed the value of } \mathrm{Hb} \text { in the } \\
\text { intervention group } \mathrm{p}=0.174 \text {, meaning } \\
\text { that there was no significant difference } \\
\text { between groups. }\end{array}$ \\
\hline 7 & $\begin{array}{l}\text { Li Xin } \\
\text { China } \\
(2012)^{20}\end{array}$ & $\begin{array}{l}\text { Desain : RCT, } \\
\mathrm{N}: 100 \text { diabetes patient (control: } 50 \text {, } \\
\text { intervention } 50 \text { ) } \\
\text { giving } 300 \mathrm{mg} \text { of turmeric }\end{array}$ & $\begin{array}{l}\text { Hb value }(\mathrm{g} / \mathrm{l}) \text { given placebo. Study for } 0,02 \\
3 \text { months } \\
\text { before } 142.64 \pm 12.04 \text { after } 147.78 \pm \\
9.84 \\
\text { Before curcumin administration } \\
141.54 \pm 11.09 \text { after } 147.58 \pm 9.82 \\
\mathrm{P} \text { value }=0.992\end{array}$ \\
\hline 8 & $\begin{array}{l}\text { Somlak } \\
\text { Thailand } \\
(2012)^{21}\end{array}$ & $\begin{array}{l}\text { Design: RCT, } \\
\text { N: } 240 \text { pre-diabetic patients (control: } \\
\text { 170, intervention } 170 \text { ) } \\
\text { Giving turmeric in capsule form }\end{array}$ & $\begin{array}{l}\text { The results of the study for } 9 \text { months - } \\
\text { showed the mean value of HbA1c } \\
\text { control } 16.02 \text { with a minimum value of } \\
5.2 \text { and a maximum of } 7.5 \\
\text { Intervention } 5.60 \text { with a minimum value } \\
\text { of } 4.9 \text { and a maximum of } 6.8 \\
\text { p value }<0.01\end{array}$ \\
\hline 9 & $\begin{array}{l}\text { Yi-Sun Yang } \\
\text { Taiwan } \\
(2014)^{22}\end{array}$ & $\begin{array}{l}\text { Desain : RCT, } \\
\mathrm{N}: 65 \text { patient sindrom metabolik } \\
\text { (kontrol: } 33 \text {, intervention } 33 \text { ) } \\
\text { giving } 630 \mathrm{mg} \text { of turmeric }\end{array}$ & $\begin{array}{l}\text { Value of HbA1c levels (\%) in the male } 0.45 \\
\text { group with the intervention. } \\
\text { The results of the study for } 12 \text { weeks } \\
\text { showed no significant change in the } \\
\text { value of HbA1c levels }\end{array}$ \\
\hline 10 & $\begin{array}{l}\text { Sang-Wook } \\
\text { Kim } \\
\text { Korea } \\
(2013)^{23}\end{array}$ & $\begin{array}{l}\text { The study design used RCT, the study } \\
\text { was conducted on } 60 \text { patients with } \\
\text { elevated alanine transaminase (ALT). } \\
\text { Turmeric powder that has been } \\
\text { fermented with } 1.0 \mathrm{~g} \text {. the control } \\
\text { group was given a placebo }\end{array}$ & $\begin{array}{l}\text { The value of } \mathrm{Hb}(\mathrm{g} / \mathrm{dL}) \text { levels in the } 0.16 \\
\text { study for } 12 \text { weeks in the intervention } \\
\text { group } \\
\text { before } 15.9 \pm 1.1 \text { after } 15.9 \pm 1.2 \\
\text { value in the control group } \\
\text { before } 15.6 \pm 1.4 \text { after } 15.7 \pm 1.3 \\
\mathrm{p}=0.21\end{array}$ \\
\hline 11 & $\begin{array}{l}\text { Nyoman Kertia } \\
\text { Indonesia } \\
(2011)^{24}\end{array}$ & $\begin{array}{l}\text { Research design using RCT, the study } \\
\text { was conducted on } 73 \text { osteoarthritis } \\
\text { patients. } 34 \text { samples were given } 3 \times 25 \\
\text { mg of curcuminoid turmeric rhizome } \\
\text { extract and } 39 \text { controls were given } \\
3 \times 25 \text { mg of diclofenac sodium }\end{array}$ & $\begin{array}{l}\text { The value of } \mathrm{Hb} \text { levels in the study for } 40.25 \\
\text { weeks in the group } \\
\text { intervention } \\
\text { before: } 12.56 \pm 1.25 \text { after: } 12.85 \pm 1.37 \\
\text { control } \\
\text { before: } 13.06 \pm 1.48 \text { after: } 12.94 \pm 1.38 \\
\text { p } 0.02\end{array}$ \\
\hline 12 & $\begin{array}{l}\text { Tatul. S } \\
\text { German } \\
(2020)^{25}\end{array}$ & $\begin{array}{l}\text { The study design used RCT, the study } \\
\text { was conducted on } 150 \text { women with } \\
\text { advanced breast cancer. Samples } \\
\text { received paclitaxel }(80 \mathrm{mg} / \mathrm{m} 2) \text { plus } \\
\text { curcumin (CUC-1 solution } 300 \mathrm{mg} \text {. }\end{array}$ & $\begin{array}{l}\text { The } \mathrm{Hb}(\mathrm{g} / \mathrm{l}) \text { value of the study was } 120.01 \\
\text { weeks } \\
\text { in the control group } \\
131.9 \pm 13.76 \\
\text { in the intervention group }\end{array}$ \\
\hline
\end{tabular}




\section{STRADA Jurnal Ilmiah Kesehatan}

DOI: $10.30994 /$ sjik.v9i2.482

ISSN: 2252-3847 (print); 2614-350X (online)

Vol.9 No.2 November 2020 Page.1422-1433

\begin{tabular}{|c|c|c|c|c|}
\hline & & & $\begin{array}{l}131.7 \pm 13.26 \\
p=0.8678\end{array}$ & \\
\hline 13 & $\begin{array}{l}\text { Jeffrey Pradeep } \\
\text { India } \\
(2020)^{26}\end{array}$ & $\begin{array}{l}\text { The study design used RCT, the study } \\
\text { was conducted on } 90 \text { patients with } \\
\text { arthritis. Giving turmeric } \\
\mathrm{P} 1=1 \mathrm{~g} \\
\mathrm{P} 2=0.5 \mathrm{~g}\end{array}$ & $\begin{array}{l}\text { The } \mathrm{Hb} g(\%) \text { value of the study was } 84 \\
\text { days } \\
\mathrm{P} 0=14.00 \pm 2.07 \\
\mathrm{P} 1=14,593 \pm 2.16 \\
\mathrm{P} 2=14.33 \pm 1.59 \\
\mathrm{p}=0.693\end{array}$ & $\begin{array}{l}\mathrm{P} 0 \& \mathrm{P} 1 \\
0.28 \\
\mathrm{P} 1 \& \mathrm{P} 2 \\
0.13 \\
\mathrm{P} 2 \& \mathrm{P} 0 \\
0.17\end{array}$ \\
\hline 14 & $\begin{array}{l}\text { Livia Alvarenga } \\
\text { Brazil } \\
(2020)^{27}\end{array}$ & $\begin{array}{l}\text { Design: RCT, } \\
\mathrm{N} \text { : } 31 \text { hemodialysis patients (control: } \\
15 \text {, intervention 16) } \\
\text { Giving } 630 \mathrm{mg} \text { of turmeric } 3 \text { times a } \\
\text { day } \\
\mathrm{P} 1 \text { : receive } 100 \mathrm{~mL} \text { of orange juice } \\
\text { with } 12 \mathrm{~g} \text { of carrots and } 2.5 \mathrm{~g} \\
\mathrm{P} 2 \text { : receive the same juice without } \\
\text { curcumin (carrots and oranges) }\end{array}$ & $\begin{array}{l}\text { The results of research conducted for } 3 \\
\text { months } \\
\text { Hb value in the curcumin group } \\
\text { before } 11.0 \pm 2.0 \text { after } 10.4 \pm 1.6 \text {. } \\
\text { the Hb value of the control group } \\
\text { before } 10.8 \pm 1.3 \text { after } 10.0 \pm 1.9 \\
\mathrm{p}=0.30\end{array}$ & 0.07 \\
\hline 15 & $\begin{array}{l}\text { Churat } \\
\text { Weeraphana } \\
\text { Thailand } \\
(2012)^{28}\end{array}$ & $\begin{array}{l}\text { Research design using RCT, the study } \\
\text { was conducted on } 20 \text { patients samples } \\
10 \text { Thalassemic patients were given } \\
250 \mathrm{mg} \text { of turmeric } 2 \mathrm{x} / \text { day in } \\
\text { capsule form and } 10 \text { healthy samples } \\
\text { were given a placebo. }\end{array}$ & $\begin{array}{l}\text { Niai Hb on control } \\
141 \pm 5 \\
\text { Hb value in the intervention group } \\
\text { before } 69 \pm 3 \text { After } 69 \pm 3 \\
\text { the results of the study for } 12 \text { months } \\
\text { showed a value of } p>0.01\end{array}$ & 17.4 \\
\hline 16 & $\begin{array}{l}\text { Esmat } \\
\text { Iran } \\
(2017)^{29}\end{array}$ & $\begin{array}{l}\text { Design: RCT, } \\
\mathrm{N}: 61 \text { thalassemia patients (control: } \\
31 \text {, intervention } 30 \text { ) } \\
\text { Giving turmeric } 500 \mathrm{mg}\end{array}$ & $\begin{array}{l}\text { Results of the study for } 12 \text { weeks } \\
\text { before } 8.39 \pm 0.61 \text { after } 8.60 \pm 0.51 \\
\text { placebo } \mathrm{Hb} \text { value } \\
\text { before } 8.44 \pm 2.03 \text { after } 8.56 \pm 1.9 \\
\text { p value }>0.05\end{array}$ & 0,007 \\
\hline 17 & $\begin{array}{l}\text { Elahe muhamad } \\
\text { Iran } \\
(2018)^{30}\end{array}$ & $\begin{array}{l}\text { Design: RCT, } \\
\mathrm{N}: \quad 68 \text { thalassemia thalassemia } \\
\text { patients (control: } 34 \text {, intervention } 34 \text { ) } \\
\text { Giving turmeric } 500 \mathrm{mg}\end{array}$ & $\begin{array}{l}\text { Hb value in the intervention group } \\
\text { before } 8.39 \pm 0.6 \text { after } 8.60 \pm 0.51 \\
\text { Hb values in the placebo group } \\
\text { before } 8.44 \pm 0.64 \\
\text { after } 8.56 \pm 0.62 \\
\text { value }(p>0.05)\end{array}$ & 0,07 \\
\hline 18 & $\begin{array}{l}\text { Ahmad } \\
\text { London } \\
(2020)^{31}\end{array}$ & $\begin{array}{l}\text { Research design with RCT conducted } \\
\text { in thalassemia patients. } 34 \text { samples } \\
\text { were given a placebo and } 34 \text { samples } \\
\text { were given } 500 \mathrm{mg} \text { of turmeric twice } \\
\text { a day in capsule form }\end{array}$ & $\begin{array}{l}\text { The results of the study for } 12 \text { weeks of } \\
\text { Hb value on turmeric administration } \\
\text { before } 8.39 \pm 0.61 \text { after } 8.60 \pm 0.51 \\
\text { Hb value on placebo } \\
\text { before } 8.44 \pm 0.64 \text { after } 8.56 \pm 0.62 \\
\text { p value }<0.05\end{array}$ & 0,09 \\
\hline 19 & $\begin{array}{l}\text { Jirawan } \\
\text { Panachan } \\
\text { Bangkok } \\
(2019)^{32}\end{array}$ & $\begin{array}{l}\text { Design: RCT, } \\
\mathrm{N}: 20 \text { ( } 10 \text { healthy patients, } 10 \\
\text { thalassemia patients) } \\
\text { Giving turmeric } 500 \mathrm{mg} \text { The control } \\
\text { group was given curcuminoids- }(\mathrm{M} / \\
\mathrm{F}=5 / 5 \text {, age } 35 \pm 3 \mathrm{Y} / \mathrm{O}) \text { or vitamin } \\
\mathrm{E} \text { antioxidant cocktail }(\mathrm{M} / \mathrm{F}=4 / 6, \\
\text { age } 34 \pm 3 \mathrm{Y} / \mathrm{O}) \text { and the control } \\
\text { group was given vitamin } \mathrm{E}\end{array}$ & $\begin{array}{l}\text { Hb value after administration for } 12 \\
\text { months } \\
\text { giving turmeric } \\
\text { before } 65.1 \pm 3.1 \text { after } 70.3 \pm 3.0 \\
\text { giving vitamin } \mathrm{E} \\
\text { before } 71.0 \pm 5.5 \text { after } 77.0 \pm 5.8 \\
\text { p value }=0.01\end{array}$ & 1,45 \\
\hline 20 & $\begin{array}{l}\text { Orn Uma } \\
\text { Thailand } \\
(2015)^{33}\end{array}$ & $\begin{array}{l}\text { The study design used an RCT } \\
\text { conducted on } 60 \text { thalassemia patients. } \\
30 \text { samples were given curcumin } 50\end{array}$ & $\begin{array}{l}\text { Results of the study for } 15 \text { weeks } \\
\text { intervention group } \\
\text { before } 61.9 \pm 2.3 \text { after } 63.9 \pm 3.8\end{array}$ & 1.22 \\
\hline
\end{tabular}




\section{STRADA Jurnal Ilmiah Kesehatan}

DOI: $10.30994 /$ sjik.v9i2.482

\begin{tabular}{|c|c|c|c|c|}
\hline & & $\begin{array}{l}\mathrm{mg} / \mathrm{kg} / \mathrm{BW} \text {. } \\
\text { and the control group was given } \\
\text { vitamin E } 400 \mathrm{Iu} / \text { day }\end{array}$ & $\begin{array}{l}\text { in the control group } \\
\text { before } 65.9 \pm 3.4 \text { after } 68.1 \pm 3.0 \\
\text { p value }<0.05\end{array}$ & \\
\hline 21 & $\begin{array}{l}\text { Saurabh Kedia } \\
\text { India } \\
(2017)^{34}\end{array}$ & $\begin{array}{l}\text { The study design using RCT research } \\
\text { was conducted on } 61 \text { patients with } \\
\text { UC (large intestine). In the } \\
\text { intervention group given } 1 \text { turmeric } \\
\text { capsule containing } 150 \mathrm{mg} \text {, each } \\
\text { sample was given capsules } 3 \text { times / } \\
\text { day. Placebo } 3 x \text { a day }\end{array}$ & $\begin{array}{l}\text { Value of } \mathrm{Hb} \text { levels for the first } 8 \text { weeks } \\
\text { curcumin: } 12.0 \pm 2.3 \\
\text { placebo: } 13.3 \pm 2.2 \\
\text { p value } 0.235 \\
\text { the last week or week } 8 \\
\text { curcumin } 12.1 \pm 2.7 \\
\text { placebo } 13.2 \pm 2.6 \\
\text { p value }=0.404\end{array}$ & - \\
\hline 22 & $\begin{array}{l}\text { N. Maithil } \\
\text { Karpaga } \\
\text { India } \\
(2015)^{35}\end{array}$ & $\begin{array}{l}\text { iRCT study design with } 60 \text { samples of } \\
\text { diabetic patients, } 30 \text { samples were } \\
\text { given turmeric powder therapy }(2 \mathrm{~g} \\
\text { per day, } 4 \text { capsules, } 500 \mathrm{mg} \text { each) } \\
\text { while the control group was given } \\
\text { metformin }\end{array}$ & $\begin{array}{l}\text { The results of the study for } 4 \text { weeks } \\
\text { in the intervention group } \\
\text { before: } 7.8 \pm 0.5 \text { after: } 7.5 \pm 0.7 \\
\text { value in the control group } \\
\text { before: } 7.9 \pm 1.3 \text { after: } 7.4 \pm 0.9 \\
\text { p value }<0.05\end{array}$ & 0.12 \\
\hline 23 & $\begin{array}{l}\text { Hamid Reza } \\
\text { Iran } \\
(2015)^{36}\end{array}$ & $\begin{array}{l}\text { RCT study design, the study was } \\
\text { conducted on } 80 \text { diabetic patients. } 35 \\
\text { samples with the intervention of } \\
\text { turmeric in nano form as much as } 80 \\
\text { mg were given orally and } 45 \text { samples } \\
\text { were given a placebo. }\end{array}$ & $\begin{array}{l}\text { Study for } 3 \text { months in the intervention } \\
\text { group } \\
\text { before } 7.59 \pm 1.74 \\
\text { after } 7.31 \pm 1.75 \\
\text { control } \\
\text { before } 7.49 \pm 1.75 \text { after } 9.00 \pm 2.33 \\
p=0.013\end{array}$ & 0.44 \\
\hline 24 & $\begin{array}{l}\text { Sepideh R } \\
\text { Iran } \\
(2016)^{37}\end{array}$ & $\begin{array}{l}\text { Design: RCT, } \\
\mathrm{N}: 80 \text { patients with non-alcoholic } \\
\text { fatty liver disease (NAFLD). (control: } \\
\text { 40, intervention } 40 \text { ) } \\
500 \text { mg of curcumin }\end{array}$ & $\begin{array}{l}\text { The results of the study for } 8 \text { weeks } \\
\text { before } 6.31 \pm 1.62 \text { after } 5.53 \pm 1.27 \\
\text { HbA1c values in the placebo group } \\
\text { before } 7.37 \pm 1.33 \text { after } 7.53 \pm 1.43 \\
\text { (p <0.001). }\end{array}$ & 0,02 \\
\hline 25 & $\begin{array}{l}\text { Yunes Panahi } \\
\text { Iran } \\
(2016)^{38}\end{array}$ & $\begin{array}{l}\text { The study design used RCT, the study } \\
\text { was conducted on } 102 \text { NAFLD } \\
\text { patients. } 50 \text { samples were given } 500 \\
\text { mg of turmeric orally twice a day and } \\
52 \text { control groups were given a } \\
\text { placebo }\end{array}$ & $\begin{array}{l}\text { The results of the study were conducted } \\
\text { for } 8 \text { weeks } \\
\text { before } 6.17 \pm 1.37 \text { after } 5.95 \pm 1.13 \\
\text { in the control group } \\
\text { before } 5.95 \pm 1.13 \text { after } 5.77 \pm 0.53 \\
\text { p value }=0.914\end{array}$ & 0.12 \\
\hline
\end{tabular}

\section{DISCUSSION}

Turmeric (Curcuma Longa) is a family of Zingiberaceae and plants from Southeast Asia. This plant is often found in tropical areas such as Bangladesh, China, Thailand, Cambodia, Malaysia, and Indonesia. ${ }^{39}$ Turmeric contains antioxidants that function to eradicate free radicals. ${ }^{40}$ Secondary antioxidants in turmeric are vitamin E and vitamin C. Secondary antioxidants are compounds that function to capture free radicals and prevent chain reactions so that greater damage does not occur. Turmeric contains $0.7 \mathrm{mg}$ of vitamin $\mathrm{C}$ and $4.43 \mathrm{mg}$ of vitamin E. Vitamin C or ascorbic acid needed in the body for men is $90 \mathrm{mg} /$ day, women $75 \mathrm{mg} / \mathrm{day}$, and a maximum of $2,000 \mathrm{mg} /$ day. ${ }^{41}$ The importance of consuming vitamin $\mathrm{C}$ for adolescent girls, especially those experiencing menstruation. someone who is deficient in vitamin $\mathrm{C}$ has a 1.58 times greater risk of suffering from anemia than individuals with sufficient vitamin $\mathrm{C}$ intake. ${ }^{42}$ Meanwhile, for those who have anemia, vitamin $\mathrm{E}$ is responsible for an imbalance of antioxidants in the body. ${ }^{29}$ Vitamin $\mathrm{E}$ can end the process of free radicals and inhibits the production of new free radicals and limits the 


\section{STRADA Jurnal Ilmiah Kesehatan}

DOI: $10.30994 /$ sjik.v9i2.482

ISSN: 2252-3847 (print); 2614-350X (online)

Vol.9 No.2 November 2020 Page.1422-1433

destruction to the boundary of the cell membrane area. ${ }^{41}$ by transferring phenolic hydrogen to the perxyl free radicals of peroxidated polyunsaturated fatty acids. ${ }^{43}$

A study conducted by Li-Xin Na (2012) said that Curcuma Longa contains antioxidants that can protect cell mitochondria from oxidative stress, which causes an increase in hemoglobin levels. ${ }^{20}$ Oxidative stress results from excessive free radicals in the body, causing oxidative damage starting from the level of cells, tissues, organs, and the emergence of other diseases. ${ }^{41}$ Apart from antioxidants, hemoglobin levels can be caused by iron de ciency. For this reason, it is necessary to increase iron in increasing hemoglobin. Turmeric contains iron as much as $55.00 \mathrm{mg} / 100$ gram which functions to form hemoglobin where hemoglobin functions to carry oxygen throughout the body. ${ }^{44}$ Theironin turmeric is easily absorbed because turmeric is a non-heme type of iron in the form of the inorganic complex $\mathrm{Fe} 3$ - to $\mathrm{Fe} 2 .^{45}$

There are 3 very important roles of vitamins that are indirectly related to iron metabolism and erythropoiesis. These contents are Thiamine $(0.058 \mathrm{mg} / 100 \mathrm{~g}$ turmeric), Niacin (1.350mg/100g turmeric) and Pantothenic Acid / B5 (0.542 mg/100g turmeric). De ciency of these 3 vitamins results in anemia and usually occurs not in humans, but rather in animals. ${ }^{45}$ The need for thiamine for the body is proportional to the daily calorie intake as a coenzyme for enzymes that act on the oxidative process of phosphorylation of keto acids. ${ }^{41}$ extensive in most animal and plant-based foods. The essential amino acid tryptophan can beconverted intoniacin $(\mathrm{NAD}+)$ where every $60 \mathrm{mg}$ of tryptophan can produce $1 \mathrm{mg}$ of niacin. ${ }^{43}$ One of the turmeric content that still affects anemia is zinc $(\mathrm{Zn})$ which contains $4.50 \mathrm{mg} / 100 \mathrm{~g}$ of turmeric. The occurrence of zinc deficiency affects iron metabolism because here zinc functions as a cofactor in the retinol oxidation reaction. Low plasma retinol concentrations are associated with decreased plasma iron and hemoglobin. Vitamin B6 is needed in protein metabolism which is also required for heme synthesis in the formation of hemoglobin. Copper is also related to the oxidation process of iron for the formation of hemoglobin. ${ }^{46}$

In addition to the vitamins above, the protein content of 6.8 grams / 100 in turmeric also affects the increase in $\mathrm{Hb}$ levels. ${ }^{47}$ The protein in turmeric functions in transporting iron in the body. Lack of protein in the body causes iron transport to be inhibited and leads to anemia. ${ }^{48}$ Cellular protein metal- binding proteins that bind/chelate prooxidant minerals such as ironandcopper and othermetals. Metal-binding protein prevents the presence of Fe2-ions for the formation of hydroxylradicals $(\mathrm{OHo})$. Molecules that areincluded as metal- binding proteins are transferrin which functions as a protein transport of iron, ferritin functions as a protein storage protein, metallothionein functions as a binding agent for minerals and other heavy metals $(\mathrm{Zn} / \mathrm{Cu} / \mathrm{Cd} / \mathrm{Hg})$, and ceruloplasmin which functions as a transport protein and copper storage. Several studies have shown there is no increase in hemoglobin levels with turmeric intervention, this is in uenced by several things such as diseases associated with blood loss such as hemodialysis, NAFLD, UC, thalassemia, prehypertension, diabetes, metabolic syndrome, patients with elevated ALT, arthritis, cancer. When the blood is lost, the iron balance in the body is disturbed, which causes anemia. $1 \mathrm{ml}$ of blood loss will result in the body losing as much as $0.5 \mathrm{mg}$ of iron which can cause a negative iron balance. ${ }^{49}$

Research conducted by Maryam on hemodiaslysis patients for 8 weeks with a dose of $500 \mathrm{mg}$ showed a value of $\mathrm{p}=0.425$ and (effect size 0.46 ). The administration of turmeric is not effective in increasing hemoglobin levels. ${ }^{14}$ The stoichiometric quality of turmeric can bind almost all of the iron that can be absorbed. and cause iron deficiency. Curcumin is the active ingredient in turmeric that can bind ferrous iron. Curcumin suppresses the synthesis of hepcidin, a peptide involved in iron balance. ${ }^{50}$ HD patients have abnormal oxidant production and damaged antioxidant production. ${ }^{27}$ This is 


\section{STRADA Jurnal Ilmiah Kesehatan}

DOI: $10.30994 /$ sjik.v9i2.482

ISSN: 2252-3847 (print); 2614-350X (online)

Vol.9 No.2 November 2020 Page.1422-1433

evidenced by Livia's research that giving turmeric to hemodialysis patients does not increase the value of $\mathrm{Hb}$ levels. ${ }^{27}$

Non-alcoholic fatty liver disease (NAFLD) is the most common chronic liver disease that is closely associated with dyslipidemia, metabolic syndrome, and cardiovascular disease. ${ }^{37}$ NAFLD causes impaired duodenal iron absorption associated with lower duodenal ferroportin expression and elevated hepcidin levels. ${ }^{51}$ NAFLD is common in patients with diabetes and obesity. ${ }^{52}$

Ulcerative colitis patients for 8 weeks had no effect on $\mathrm{Hb}$ levels. Several other studies have shown a decrease in $\mathrm{Hb}$ levels after being given turmeric intervention. UC patients are characterized by inflammation and mucosal ulceration. ${ }^{34,18}$ This inflammation causes an increase in hepcidin which in turn inhibits iron absorption from the intestinal lumen. ${ }^{52}$

In thalassemia, iron absorption becomes poor due to the frequent transfusion process. The hepatic peptide hepcidin inhibits the entry of iron into plasma through several mechanisms and regulates iron homeostasis in the body.in $\beta$ - thalassemia, ineffective erythropoiesis causes a compensatory decrease in hepcidin expression and consequently results in increased intestinal iron absorption. . $^{29,30,53}$

In Sepideh's study, it was shown that giving turmeric in capsule form $(500 \mathrm{mg})$ can reduce HbA1c levels. Hemoglobin A1c is a small component of hemoglobin HbA1c used to monitor blood glucose in diabetic patients. Hemoglobin is found in red blood cells that carry oxygen throughout the body. When diabetes is not controlled, sugarwill accumulate in the blood andcombine with hemoglobin so that it becomes glycated. ${ }^{37}$

The existence of differences in subjects can affect the value of Hb levels. In theory, it is revealed that certain body conditions or diseases can affect the $\mathrm{Hb}$ level in each sample. In addition to disease factors, several studies were also in uenced by differences in the characteristics of research subjects of each article, the duration of intervention or administration, the number of times the frequency of turmeric was given, the amount of turmeric given, the form of turmeric dosage given in each article.

\section{CONCLUSION}

Based on the analysis of 25 articles related to turmeric research (Curcuma Longa) in subjects with various diseases related to blood loss, there are only 3 articles that show an increase in $\mathrm{Hb}$ levels after giving Curcuma Longa both in terms of effect size and from the p-value, These 3 articles were conducted by Jirawan Panachan, Hamid Reza and Orn Uma. Soitcan be concluded that Curcuma Longa is not effective in increasing hemoglobin levels.

\section{REFERENCES}

1. WHO, UNICEF, UNFPA, Group WB, Division the UNP. WHO | Trends in maternal mortality: 1990 to 2015. World Health Organization. 2015.

2. Alkema L, Chou D, Hogan D, Zhang S, Moller AB, Gemmill A, et al. Global, Regional, and National Levels and Trends in Maternal Mortality Between 1990 and 2015, with Scenario-Based Projections to 2030: A Systematic Analysis by the UN Maternal Mortality Estimation Inter-Agency Group. Lancet. 2015;387(10017):46274.

3. Kesehatan K, Indonesia R. Profil Kesehatan Indonesia. 2017.

4. 2014 PMKRIN 97 T. Pelayanan Kesehatan Masa Sebelum Hamil, Masa Hamil, Persalinan dan Masa sesudah Melahirkan, Penyelenggaraan Pelayanan Kontrasepsi Serta Pelayanan Kesehatan Seksual. 


\section{STRADA Jurnal Ilmiah Kesehatan}

DOI: $10.30994 /$ sjik.v9i2.482

ISSN: 2252-3847 (print); 2614-350X (online)

Vol.9 No.2 November 2020 Page.1422-1433

5. World Health Organization. Worldwide Prevalence Of Anemia: WHO Global database on Anemia. Geneva: WHO Press.2013.

6. Kementerian Kesehatan Republik Indonesia. Hasil Riset Kesehatan Dasar Kementerian RI 2013. 2013;6. Available from: http://www.depkes.go.id/resources/download/general/Hasil Riskesdas 2013.pdf

7. Departemen Kesehatan RI. Survey Kesehatan Rumah Tangga. in Jakarta. 2013;

8. Indonesia KKR. Pedoman Pencegahan dan Penganggulangan Anemia Pada Remaja Putri Dan Wanita Usia Subur (WUS). In 2016.

9. Susanti Y, Briawan D, Martianto D. Suplementasi Besi Mingguan Meningkatkan Hemoglobin Sama Efektif Dengan Kombinasi Mingguan Dan Harian Pada Remaja Putri. Supl Besi Mingg Meningkat Hemoglobin Sama Ef Dengan Komb Mingg Dan Hari Pada Remaja Putri. 2016;11(1):27-34.

10. Sarliana. Ekstrak Buah Tomat Memperbaiki Status Anemia Pada Ibu Hamil Yang Mendapatkan Suplementasi Tablet Fe (Studi Di Wilayah Kerja Puskesmas Kota Semarang) . Poltekkes Kemenkes :Semarang. 2018;2018.

11. Angela D. Potensi Ekstrak Daun Jambu Biji (Psidii Folium) Sebagai Bahan Alternatif Terhadap Kadar Hemoglobin Dan Kadar Ferritin Pada Remaja Puteri (Studi Kasus Remaja Puteri Di Smk Bhakti Nusantara) . Poltekkes Kemenkes :Semarang. 2019;2019.

12. Nor SN, R M, D S. Pengaruh penambahan kunyit dan jahe dalam ransum, terhadap eritrosit, leukosit dan hemoglobin puyuh jantan. J Pengamangan Penyul Pertan. 2017;91-9.

13. Hanifa K, Murwani R, Isroli. Pengaruh Pemberian Air Kunyit (Curcuma Domestica) terhadap Profil Darah Merah ( Jumlah Eritrosit, Hemoglobin dan Hematokrit) pada Ayam Broiler. J Chem Inf Model. 2019;53(9):1689-99.

14. Pakfetrat M, Akmali M, Malekmakan L, Dabaghimanesh M, Khorsand M. Role of turmeric in oxidative modulation in end-stage renal disease patients. Hemodial Int. 2015;19(1):124-31.

15. Kalpravidh RW, Siritanaratkul N, Insain P, Charoensakdi R, Panichkul N, Hatairaktham S, et al. Improvement in oxidative stress and antioxidant parameters in $\beta$-thalassemia/Hb E patients treated with curcuminoids. Clin Biochem [Internet]. 2010;43(4-5):424-9. Available

from: http://dx.doi.org/10.1016/j.clinbiochem.2009.10.057

16. Panahi Y, Valizadegan G, Ahamdi N, Ganjali S, Majeed M, Sahebkar A. Curcuminoids plus piperine improve nonalcoholic fatty liver disease: A clinical trial. J Cell Biochem. 2019;120(9):15989-96.

17. Lang A, Salomon N, Wu JCY, Kopylov U, Lahat A, Har-Noy O, et al. Curcumin in Combination With Mesalamine Induces Remission in Patients With Mild-to-Moderate Ulcerative Colitis in a Randomized Controlled Trial. Clin Gastroenterol Hepatol [Internet]. 2015;13(8):1444-1449.e1. Available from: http://dx.doi.org/10.1016/j.cgh.2015.02.019

18. Sadeghi N, Mansoori A, Shayesteh A, Hashemi SJ. The effect of curcumin supplementation on clinical outcomes and inflammatory markers in patients with ulcerative colitis. Phyther Res. 2019;(April):1-11.

19. Uchio R, Muroyama K, Okuda-Hanafusa C, Kawasaki K, Yamamoto Y, Murosaki S. Hot water extract of Curcuma longa L. Improves serum inflammatory markers and general health in subjects with overweight or prehypertension/mild hypertension: A randomized, double-blind, placebo-controlled trial. Nutrients. 2019;11(8):1-17. 


\section{STRADA Jurnal Ilmiah Kesehatan}

DOI: $10.30994 /$ sjik.v9i2.482

ISSN: 2252-3847 (print); 2614-350X (online)

Vol.9 No.2 November 2020 Page.1422-1433

20. Na LX, Li Y, Pan HZ, Zhou XL, Sun DJ, Meng M, et al. Curcuminoids exert glucoselowering effect in type 2 diabetes by decreasing serum free fatty acids: A doubleblind, placebo-controlled trial. Mol Nutr Food Res. 2013;57(9):1569-77.

21. Chuengsamarn S, Rattanamongkolgul S, Luechapudiporn R, Phisalaphong C, Jirawatnotai S. Curcumin extract for prevention of type 2 diabetes. Diabetes Care. 2012;35(11):2121-7.

22. Yang YS, Su YF, Yang HW, Lee YH, Chou JI, Ueng KC. Lipid-lowering effects of curcumin in patients with metabolic syndrome: A randomized, double-blind, placebocontrolled trial. Phyther Res. 2014;28(12):1770-7.

23. Kim SW, Ha KC, Choi EK, Jung SY, Kim MG, Kwon DY, et al. The effectiveness of fermented turmeric powder in subjects with elevated alanine transaminase levels: A randomised controlled study. BMC Complement Altern Med [Internet]. 2013;13(1):1. Available from: BMC Complementary and Alternative Medicine

24. Kertia N, Asdie AH, Rochmah W. Perubahan kadar hemoglobin akibat terapi kurkuminoid ekstrak rimpang kunyit dibandingkan natrium diklofenak pada penderita osteoartritis. J Gizi Klin Indones. 2011;7, no 3:146-52.

25. Saghatelyan T, Tananyan A, Janoyan N, Tadevosyan A, Petrosyan H, Hovhannisyan A, et al. Efficacy and safety of curcumin in combination with paclitaxel in patients with advanced, metastatic breast cancer: A comparative, randomized, double-blind, placebo-controlled clinical trial. Phytomedicine [Internet]. 2020;70(March):153218. Available from: https://doi.org/10.1016/j.phymed.2020.153218

26. Raj JP, Venkatachalam S, Racha P, Bhaskaran S, Amaravati RS. Effect of Turmacin supplementation on joint discomfort and functional outcome among healthy participants - A randomized placebo-controlled trial. Complement Ther Med [Internet]. 2020;53(March):102522. Available from: https://doi.org/10.1016/j.ctim.2020.102522

27. Alvarenga L, Salarolli R, Cardozo LFMF, Santos RS, de Brito JS, Kemp JA, et al. Impact of curcumin supplementation on expression of inflammatory transcription factors in hemodialysis patients: A pilot randomized, double-blind, controlled study. Clin Nutr [Internet]. 2020; $(\mathrm{xxxx}) . \quad$ Available from: https://doi.org/10.1016/j.clnu.2020.03.007

28. Weeraphan C, Srisomsap C, Chokchaichamnankit D, Subhasitanont P, Hatairaktham $\mathrm{S}$, Charoensakdi R, et al. Role of curcuminoids in ameliorating oxidative modification in $\beta$-thalassemia/Hb E plasma proteome. J Nutr Biochem. 2012;24(3):578-85.

29. Nasseri E, Mohammadi E, Tamaddoni A, Qujeq D, Zayeri F, Zand H. Benefits of Curcumin Supplementation on Antioxidant Status in $\beta$-Thalassemia Major Patients: A Double-Blind Randomized Controlled Clinical Trial. Ann Nutr Metab. 2018;71(34):136-44.

30. Mohammadi E, Tamaddoni A, Qujeq D, Nasseri E, Zayeri F, Zand H, et al. An investigation of the effects of curcumin on iron overload, hepcidin level, and liver function in $\beta$-thalassemia major patients: A double-blind randomized controlled clinical trial. Phyther Res. 2018;32(9):1828-35.

31. Tamaddoni A, Nasseri E, Mohammadi E, Qujeq D, Zayeri F, Zand H, et al. A Doubleblind Randomized Controlled Trial of Curcumin for Improvement in Glycemic Status, Lipid Profile and Systemic Inflammation in $\beta$-Thalassemia Major. J Herb Med [Internet]. 2020;100324. Available from: https://doi.org/10.1016/j.hermed.2019.100324

32. Panachan J, Chokchaichamnankit D, Weeraphan C, Srisomsap C, Masaratana P, 


\section{STRADA Jurnal Ilmiah Kesehatan}

DOI: $10.30994 /$ sjik.v9i2.482

ISSN: 2252-3847 (print); 2614-350X (online)

Vol.9 No.2 November 2020 Page.1422-1433

Hatairaktham S, et al. Differentially expressed plasma proteins of $\beta$ thalassemia/hemoglobin $\mathrm{E}$ patients in response to curcuminoids/vitamin $\mathrm{E}$ antioxidant cocktails. Hematol (United Kingdom). 2019;24(1):300-7.

33. Yanpanitch OU, Hatairaktham S, Charoensakdi R, Panichkul N, Fucharoen S, Srichairatanakool S, et al. Treatment of $\beta$-thalassemia/hemoglobin e with antioxidant cocktails results in decreased oxidative stress, increased hemoglobin concentration, and improvement of the hypercoagulable state. Oxid Med Cell Longev. 2015;2015:8.

34. Kedia S, Bhatia V, Thareja S, Garg S, Mouli VP, Bopanna S, et al. Low dose oral curcumin is not effective in induction of remission in mild to moderate ulcerative colitis: Results from a randomized double blind placebo controlled trial. World J Gastrointest Pharmacol Ther. 2017;8(2):147.

35. Maithili Karpaga Selvi N, Sridhar MG, Swaminathan RP, Sripradha R. Efficacy of Turmeric as Adjuvant Therapy in Type 2 Diabetic Patients. Indian J Clin Biochem. 2015;30(2):180-6.

36. Hamid Reza Rahimi, Mohammadpour AH, Dastani M, Jaafari MR, Abnous K, Mobarhan MG, et al. The effect of nano-curcumin on HbA1c, fasting blood glucose, and lipid profile in diabetic subjects: a randomized clinical trial. 2016;6 no 5.

37. Rahmani S, Asgary S, Askari G, Keshvari M, Hatamipour M, Feizi A, et al. Treatment of Non-alcoholic Fatty Liver Disease with Curcumin: A Randomized Placebocontrolled Trial. Phyther Res. 2016;(May):1540-8.

38. Panahi Y, Kianpour P, Mohtashami R, Jafari R, Simental-Mendiá LE, Sahebkar A. Curcumin Lowers Serum Lipids and Uric Acid in Subjects with Nonalcoholic Fatty Liver Disease: A Randomized Controlled Trial. J Cardiovasc Pharmacol. 2016;68(3):223-9.

39. Nwaekpe J, Anyaegbunam H, Okoye B, Asumugha G. Promotion of Turmeric for the Food/Pharmaceutical Industry in Nigeria. Am J Exp Agric. 2015;8(6):335-41.

40. Taoheed AA, Tolulope AA, Saidu AB, Odewumi OG, Sunday RM, Usman M. Phytochemical Properties, Proximate and Mineral Composition of Curcuma longa Linn . and Zingiber officinale Rosc .: A Comparative Study. 2017;13(4):1-7.

41. Yuslianti E reni. Pengaruh Radikal Bebas terhadap Kerusakan Sel dan Penyakit Manusia | Antioksidan | Mekanisme Kerja Antioksidan. In Yogyakarta: Penerbit Deepublish (Grup Penerbitan CV Budi Utama); 2018.

42. Sholicha CA, Muniroh L. Hubungan Asupasdsadsadan Zat Besi, Protein, Vitamin C Dan Pola Menstruasi Dengan Kadar Hemoglobin Pada Remaja Putri di SMAN 1 Manyar Gresik. Media Gizi Indones. 2019;14(2):147-53.

43. Triana V. Macam-Macam Vitamin Dan Fungsinya Dalam Tubuh Manusia. J Kesehat Mayarakat. 2006;1(1):40-7.

44. Indonesia KKR. Pusat Pendidikan Sumber Daya Manusia Kesehatan Badan Pengembangan dan Pemberdayaan Sumber Daya Manusia Kesehatan. In 2017. p. 6-8.

45. Briawan D. Anemia Masalah Gizi Pada Remaja Wanita. EGC: Jakarta); 2016.

46. Cendani C, Murbawani EA. Asupan Mikronutrien, Kadar Hemoglobin dan Kesegaran Jasmani Remaja Putri. Media Med Indones. 2011;45(1):26-33-33.

47. Sethy K, Swain P, Behera K, Nayak SM, Barik SR, Patro P, et al. Effect of Turmeric ( Curcuma Longa ) Supplementation on Growth and Blood Chemistry of Broilers. Explor Anim Med Res,. 2016;6(2007):75-9.

48. Eniwati, Sofyan Musyabiq, Nisa Karima RG. Hubungan Asupan Protein Nabati Dengan Kadar Hemoglobin Pada Wanita Usia Remaja Vegan. Univ Lampung. 2019;9:233-6. 


\section{STRADA Jurnal Ilmiah Kesehatan}

DOI: $10.30994 /$ sjik.v9i2.482

ISSN: 2252-3847 (print); 2614-350X (online)

Vol.9 No.2 November 2020 Page.1422-1433

49. Fitriany J, Saputri AI. Anemia Defisiensi Besi. Jurnal. Kesehat Masy. 2018;4(1202005126):1-30.

50. Smith TJ, Ashar BH. Iron Deficiency Anemia Due to High-dose Turmeric. Cureus. 2019;11(1):2017-20.

51. Yıldırım Ö, Demircan T, Tüfekçi Ö, Kızılca Ö, Kuyum P, Kır M, et al. Anemia and its effect on cardiovascular findings in obese adolescents. Turkish $\mathrm{J}$ Hematol. 2018;35(3):192-6.

52. Siddique A, Nelson JE, Aouizerat B, Yeh MM, Network KVK for the NCR. Iron Deficiency In Patients With Nonalcoholic Fatty Liver Disease Is Associated With Obesity, Female Sex And Low Serum Hepcidicin. Bone. 2013;23(1):1-7.

53. Tomas Ganz, Ph.D., M.D. and Elizabeta Nemeth PD, Ganz T, Nemeth E. Hepcidin and iron homeostasis. Biochim Biophys Acta [Internet]. 2014;1823(9):1434-43. Available

from: http://www.pubmedcentral.nih.gov/articlerender.fcgi?artid=4048856\&tool=pmcentrez \&rendertype $=$ abstract 